\title{
Human stampedes at mass gatherings: An overview
}

\author{
Lakshmi Devi Vanumu' ${ }^{1}$, Laxmikant ${ }^{2}$, K.Ramachandra Rao ${ }^{3}$ \\ 1,2,3 Department of Civil Engineering, Indian Institute of Technology, Delhi \\ Hauz Khas, New Delhi, India \\ lakshmidevivanumu@gmail.com; kumar.laxmikant24@gmail.com \\ rrkalaga@civil.iitd.ac.in
}

\begin{abstract}
The main aim of this study is to present an overview of human stampedes and to identify the major triggering factors with respect to the type of events leading to number of fatalities and injuries. Considering major crowd incidents, the stampedes were categorized based on location, triggering factor, type of event and year of occurrence. This paper lists a total of 137 stampedes occurred all over the world between the years 1883 and 2017. The details include the name and type of event, location of the event, number of injuries and fatalities, probable reason for the stampede and type of reliable source. Stampedes are classified based on type of events as religious, sports, entertainment, festival, political and others. Among all types of events, religious gatherings cause $64 \%$ of total fatalities and $51 \%$ injuries. The triggering factors are identified as rumours, fire, structural failure, narrow passage, overcrowding and others. Out of all the triggering factors mentioned above, narrow passage causes about $27 \%$ fatalities followed by overcrowding and rumours with 23 and $21 \%$ respectively. The majority of injuries caused by overcrowding turn out to be $35 \%$. It is also observed that the frequency of stampede occurrences increasing since 1980. This study can be considered as an initial step in giving an overview of human stampedes, which would help to prepare a framework based on the past experiences. Further, it can give better insights for large-scale crowd management and to minimize the loss of human lives in future.
\end{abstract}

Keywords: Human stampedes, Triggering Factors, Fatalities, Injuries

\section{Background}

Human stampedes can occur at mass gatherings due to several reasons such as high crowd densities, physical and psychological problems of humans and crowd management issues etc. which leads to injuries and fatalities. Few researchers have addressed the need of studying human stampedes. Based on the number of deaths and injuries, Ngai et al., [1] proposed a logarithmic scale ranging from Class I to V to classify the human stampedes. This unique categorization may help the researchers and scientists to understand the characteristics of stampedes for systematic investigation and further analysis. Illiyas et al., [2] identified that majority of human stampedes occurred in India are in religious gatherings. Ngai et al., [3] tried to estimate the degree of underreporting of human stampedes in India by using two different methods. For a systematic investigation of epidemiological characteristics of stampedes, they have emphasized the need of an international standardized database that can record the human stampedes occurring all over the world. Alaska et al., [4] highlighted that the crowd control measures such as use of crowd simulation models, video monitoring, modification of transport system etc. were adopted during Hajj played a crucial role in improving the safety. The current study made an attempt to present an overview of human stampedes and to identify the major triggering factors with respect to the type of events leading to number of fatalities and injuries.

\section{Analysis}

Data related to human stampedes were collected from various sources such as reports, journal publications, different search engines etc. After a thorough review of literature, the stampedes were categorized based on location, triggering factor, type of event and year of occurrence. A total of 137 stampedes occurred all over the world between the years 1883 and 2017 were considered in this paper. The details include the name and type of event, location of the event, number of injuries and fatalities, probable reason for the stampede, and type of reliable source. Stampedes are classified based on type of 
events as religious, sports, entertainment, festival, political and others. Among all types of events, religious gatherings cause $64 \%$ of total fatalities and 51\% injuries. Further, it is observed that most of the peak values in Fig. 1 representing the fatalities and injuries occurred in different years are related to various religious events. This observation is in concurrence with the findings of [5] reporting that majority of the stampedes occurred in India and Saudi Arabia. Some of the major stampedes were described in table 1. The triggering factors are identified as rumours, fire, structural failure, narrow passage, overcrowding and others. Out of all the triggering factors mentioned above, narrow passage causes about $27 \%$ fatalities followed by overcrowding and rumours with 23 and $21 \%$ respectively. The majority of injuries caused by overcrowding turn out to be $35 \%$. Proportion of fatalities with respect to type of event and impact of triggering factors on number of injuries, fatalities are shown in Fig.2.

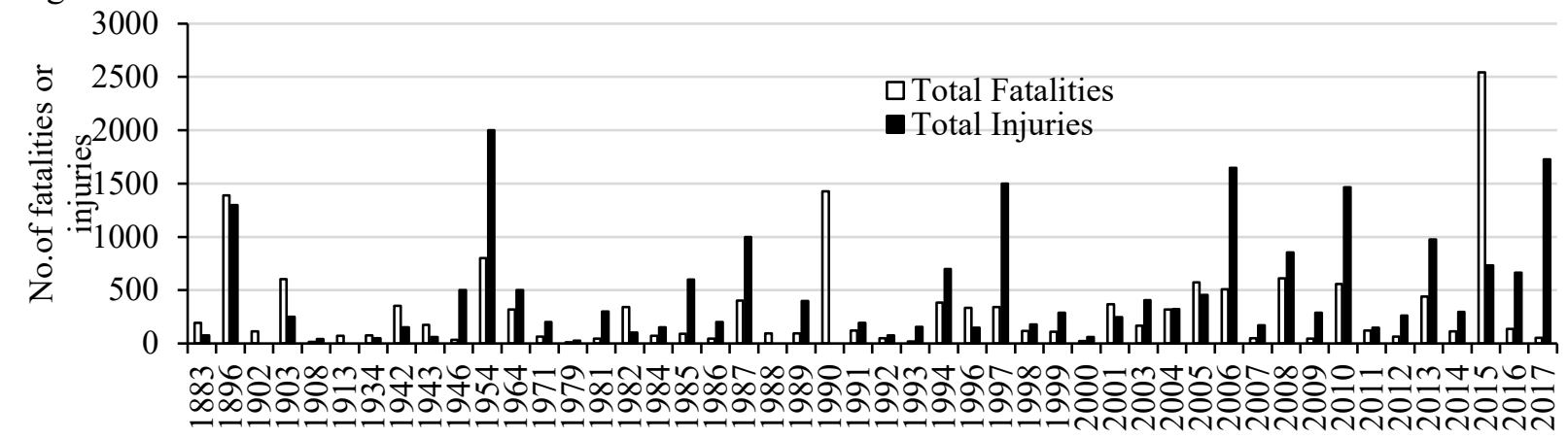

Fig. 1: Total number of fatalities and injuries with respect to year of all the events

Table 1: Description of some major stampedes

\begin{tabular}{|c|c|c|c|c|c|c|c|c|}
\hline $\begin{array}{c}\text { S. } \\
\text { No }\end{array}$ & $\begin{array}{l}\text { Name of } \\
\text { the Event }\end{array}$ & Year & Country & Location & Fatalities & Injuries & $\begin{array}{c}\text { Type of } \\
\text { Event }\end{array}$ & $\begin{array}{c}\text { Triggering } \\
\text { factor }\end{array}$ \\
\hline 1 & $\begin{array}{l}\text { Nicholas } \\
\text { Coronation }\end{array}$ & 1896 & Russia & Moscow & 1389 & $1300+$ & Festival & Rumour \\
\hline 2 & $\begin{array}{l}\text { Iroquois } \\
\text { Theatre Fire }\end{array}$ & 1903 & $\begin{array}{l}\text { United } \\
\text { States }\end{array}$ & Chicago & 602 & 250 & Entertainment & Fire \\
\hline 3 & $\begin{array}{c}\text { Peru } \\
\text { Stampede }\end{array}$ & 1964 & Peru & Lima & 318 & 500 & $\begin{array}{c}\text { Sporting } \\
\text { ingress }\end{array}$ & Tear Gas \\
\hline 4 & Hajj & 1987 & $\begin{array}{c}\text { Saudi } \\
\text { Arabia }\end{array}$ & $\begin{array}{l}\text { Mina, } \\
\text { Mecca }\end{array}$ & 402 & 1000 & Religious & $\begin{array}{l}\text { Conflict } \mathrm{b} / \mathrm{w} \\
\text { people }\end{array}$ \\
\hline 5 & Hajj & 1990 & $\begin{array}{l}\text { Saudi } \\
\text { Arabia }\end{array}$ & $\begin{array}{l}\text { Mina, } \\
\text { Mecca }\end{array}$ & 1426 & - & Religious & $\begin{array}{l}\text { Narrow } \\
\text { Passage }\end{array}$ \\
\hline 6 & Hajj & 1994 & $\begin{array}{l}\text { Saudi } \\
\text { Arabia }\end{array}$ & $\begin{array}{l}\text { Mina, } \\
\text { Mecca }\end{array}$ & 270 & 200 & Religious & Overcrowding \\
\hline 7 & $\begin{array}{c}\text { Wai } \\
\text { Stampede }\end{array}$ & 2005 & India & $\begin{array}{c}\text { Wai, } \\
\text { Maharashtra }\end{array}$ & 267 & 200 & Religious & Wet Floor \\
\hline 8 & $\begin{array}{c}\text { Mandhar } \\
\text { Devi temple }\end{array}$ & 2005 & India & $\begin{array}{c}\text { Satara, } \\
\text { Maharashtra }\end{array}$ & 258 & 200 & Religious & Fire \\
\hline 9 & Hajj & 2006 & $\begin{array}{l}\text { Saudi } \\
\text { Arabia }\end{array}$ & $\begin{array}{l}\text { Mina, } \\
\text { Mecca }\end{array}$ & 380 & 1000 & Religious & Overcrowding \\
\hline 10 & $\begin{array}{l}\text { Naina Devi } \\
\text { Temple }\end{array}$ & 2008 & India & $\begin{array}{l}\text { Himachal } \\
\text { Pradesh }\end{array}$ & 163 & 48 & Religious & Rumour \\
\hline 11 & $\begin{array}{l}\text { Phnom } \\
\text { Penh }\end{array}$ & 2010 & Cambodia & Phnom Penh & 347 & 395 & Entertainment & Rumour \\
\hline 12 & Sabarimala & 2011 & India & $\begin{array}{l}\text { Pullumedu, } \\
\text { Kerala }\end{array}$ & 102 & $100+$ & Religious & $\begin{array}{l}\text { Narrow } \\
\text { Passage }\end{array}$ \\
\hline 13 & Hajj & 2015 & $\begin{array}{l}\text { Saudi } \\
\text { Arabia }\end{array}$ & $\begin{array}{l}\text { Mina, } \\
\text { Mecca }\end{array}$ & 2431 & 427 & Religious & $\begin{array}{l}\text { Narrow } \\
\text { Passage }\end{array}$ \\
\hline 14 & $\begin{array}{c}\text { Puttingal } \\
\text { Devi temple }\end{array}$ & 2016 & India & Kerala & 106 & 383 & Religious & fire \\
\hline
\end{tabular}



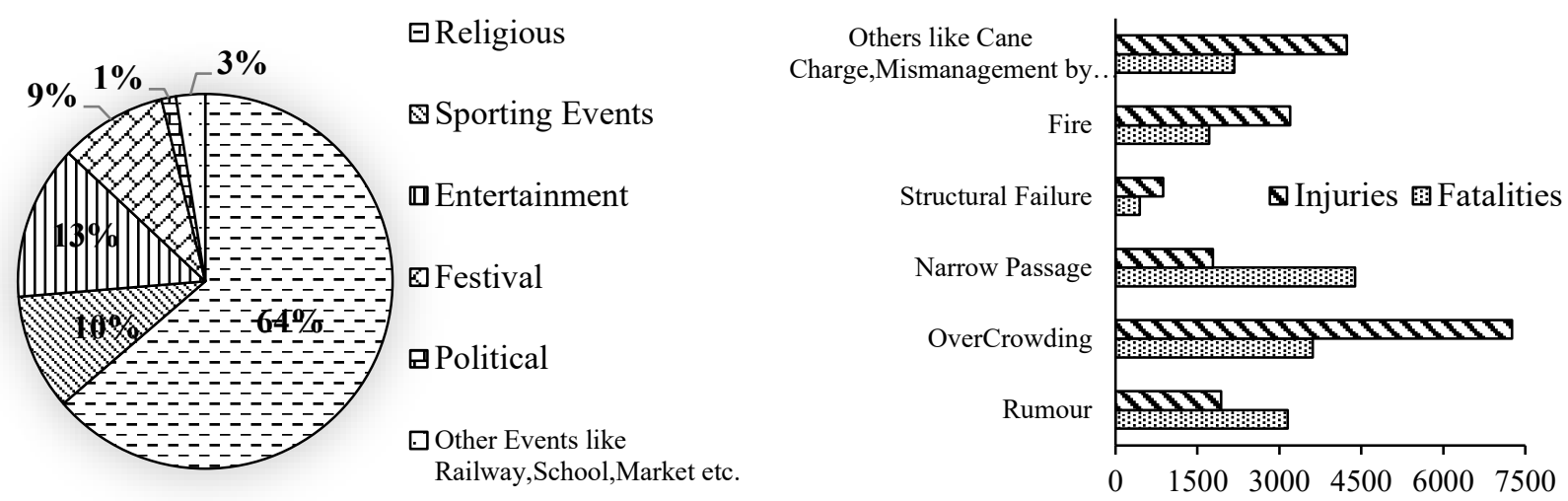

Fig. 2: (a) Distribution of fatalities with respect to type of event (b) Influence of triggering factors on injuries and fatalities.

\section{Conclusion}

The study presents an overview of human stampedes occurred all over the world. It is observed that the frequency of stampede occurrences increasing since 1980 and most of the stampedes are happened in religious gatherings. The major triggering factors in various stampedes were identified as narrow passage, overcrowding and rumours. This study can be considered as an initial step in giving an overview of human stampedes, which would help to prepare a framework based on the past experiences. Further, it can give better insights for large-scale crowd management and to minimize the loss of human lives in future.

\section{References}

[1] K.M. Ngai, F.M. Burkle, A. Hsu and E.B. Hsu, "Human stampedes: a systematic review of historical and peer-reviewed sources," Disa. Med. Pub. Health Pre., vol.3, no.4, pp.191-5, 2009.

[2] F.T. Illiyas, S.K. Mani, A.P. Pradeepkumar, K. Mohan, "Human stampedes during religious festivals: A comparative review of mass gathering emergencies in India," Int. Jour. Dis. Risk. Red., vol.5, pp.10-18, 2013.

[3] K.M. Ngai, W.Y. Lee, A. Madan, S. Sanyal, N. Roy, F.M. Burkle Jr and E.B. Hsu, "Comparing two epidemiologic surveillance methods to assess underestimation of human stampedes in India," PloS. Cur., vol.23, no.5, 2013.

[4] Y.A. Alaska, A.D. Aldawas, N.A. Aljerian, Z.A.Memish and S.Suner, "The impact of crowd control measures on the occurrence of stampedes during mass gatherings: the Hajj experience," Travel. Med. Inf. Disease. vol.15, pp.67-70, 2017.

[5] Y.H. Hsieh, K.M. Ngai, F.M. Burkle and E.B. Hsu, "Epidemiological characteristics of human stampedes," Disa. Med. Pub. Health Pre., Vol.3, no.4, pp.217-23, 2009.

[6] Hoseinpourfard, Mohammadjavad, G. Mostafa, T. Shahram, A. Ali and I. Morteza. "The Emergence of Hajj Stampedes: Lessons for Draw near in the Islamic Values in Hajj Trauma Centers Accreditation." Trauma. Mon. Published online 2016.

[7] E.B. Hsu and F.M. Burkle, "Cambodian Bon Om Touk stampede highlights preventable tragedy," Prehospital. Dis. Med., vol.27, no.5, pp.481-2. 2012.

[8] S. Parkash. (2016, April 10). Brief Report on Reconnaissance Study of Puttingal Temple Fire Incident Paravur, Kollam District, Kerala State 10.13140/RG.2.1.1782.4249.

[9] A tragedy remembered NFPA Journal July/August 1995.

[10] India disaster report (2011, June). National Institute of Disaster Management. 